\title{
Theoretical and Methodical Approaches to the Estimation of the Income of the United Territorial Communities
}

\author{
Mariia Bondarchuk \\ Department of Finance \\ National University «Lviv \\ Polytechnics» \\ Lviv, Ukraine \\ mbondarchuk@i.ua \\ http://orcid.org/0000-0002-4624-0734
}

\author{
Olga Gonchar \\ Department of Marketing and Trade \\ Entrepreneurship \\ Khmelnytskyi National University \\ Khmelnytskyi, Ukraine \\ o.i.gonchar@i.ua \\ http://orcid.org/0000-0003-3917-7586
}

\author{
Khrystyna. Dzhuryk \\ Department of Finance \\ National University «Lviv \\ Polytechnics» \\ Lviv, Ukraine \\ dxb180987@gmail.com \\ http://orcid.org/0000-0002-7100-8128
}

\begin{abstract}
The purpose of the work is to outline the role of financial actors in the effective functioning of the united territorial communities (UTC). Effective financial support for the development of the territories of Ukraine is the main objective of decentralization and reform of the administrativeterritorial system. It has been established that participation in UTCs of banks, insurance, leasing, trust, investment companies, etc. will facilitate financial interactions within UTC, as financial and credit institutions accumulate the main source of financing of the economy - money capital. In this context, it became necessary to develop theoretical and methodological approaches to assessing the incomes of different participants in UTC. A model for assessing the income of banks, insurance companies and enterprises within the combined territorial communities is developed, which will ensure the development of economic science and practice in the field of UTC activities. As a result of the study, the integrated income of each of the participants in the united territorial community was determined from their joint participation at the appropriate time. To solve the problems of financial development of UTC, issues of theoretical and methodical principles for the regulation of financial transformations of UTC, management of financial risks in UTC, diagnostics of possible crisis phenomena in the strategic development of UTCs, their emergence remain relevant .
\end{abstract}

Keywords - united territorial communities, incomes, banks, insurance companies, finances, methods of evaluation

\section{INTRODUCTION}

An important role in the activity of the united territorial community is played by the financial block. This block may include various types of financial and credit institutions: banks, insurance companies, pension funds, investment institutions (investment funds and investment companies), credit unions, factoring and leasing companies, construction financing funds (real estate fund). However, for all of them, the loud function is to raise capital for priority investment projects in UTC.

The role of these institutions in the formation and operation of the UTC is extremely important. Financial institutions operate in UTC in three main areas that influence the specific features of their activities: accumulation of free capital of enterprises and money of the population; provision of loan capital to enterprises and the state; possession of financial capital.
In this regard, there are questions regarding the development of theoretical and methodological approaches to the assessment of incomes of enterprises, a bank, an insurance company in their joint cooperation..

\section{StATEMENT OF THE PROBLEM}

The Ukrainian School of Financial Evaluation of the Activity of the Unified Territorial Communities is being developed on the basis of studies by D. Vasilkovsky [3], M. Voinarenko [3], M. Kizim, M. Kozoriz, O. Kuzmin, A. Krisovatoy, M. Krupki, T. Kutsenko [8], V. Nizhnikova [3], T. Smovzhenko, O. Tymoshenko [13], and many other scientists. Among modern researches of this problem it is necessary to highlight the work of Boronis V. [1], Gonchar O. [5], Demyanchuk O. [6], Palchuk V. [11], Khisteva O. [13] and many other scientists and practitioners. , which differently evaluate the role and significance, functions and tasks of financial and credit participants in UTC. The aim of the study is, firstly, the definition of the role of banks, insurance companies in the combined territorial communities, and secondly, the outline and the construction of a model that takes into account the income received by each participant UTC in their joint cooperation.

\section{RESULTS}

Effective financial support for the development of the territories of Ukraine is the main objective of decentralization and reform of the administrative-territorial system. Therefore, $[2 ; 3 ; 7 ; 9 ; 12]$ that the role of financial and credit participants and enterprises in UTC is decisive.

The role of banks in UTC is as follows:

1) commercial banks integrate the activities of three entities: financial (bank, insurance company, investment company, pension fund, consulting firm, brokerage offices, foreign economic units); production (production enterprises) and commercial (foreign trade companies, transport companies, etc.). Banks - UTC entities are able to significantly reduce the risk of investment through the control of users of loans and participation in the development of business plans; 2) banks can promote beneficial business contacts of enterprises and organizations that are part of UTC ; 3) banks can efficiently mobilize, distribute and redistribute and temporarily free funds of all entities of UTC in order to achieve the best final economic 
result of UTC as a whole; 4) banks are interested in the continuous improvement and regulation of cash resources within the framework of UTC ; 5) banks are the main tool for attracting foreign investment.

The investment activity of the insurance company UTC is one of the main factors in ensuring its effective functioning, including well-organized investment activity:

- determines the possibility of providing insurance services due to the formation of sufficient amount of insurance reserves;

- provides to a certain extent the quality of insurance services and determines the market position of the insurer;

- affects the cost of the insurance product and the actual performance of obligations by the insurer, due to the term of insurance payments;

- gives the opportunity to the owners of insurance companies to develop business: by investing insurance reserves there is accumulation of funds to increase its own resources.

In developed countries, insurance companies in terms of investment in the economy (and in particular) exceed the generally accepted investors - banks and investment funds $[2 ; 3]$. This situation is real, since the volume of insurance reserves and the term of their placement make insurance companies the most powerful financial and credit institutions. One of the possible tendencies in the cooperation of the financial sector of UTC is the active interaction and even the unification of banks and insurance companies.

It is proved that close cooperation between banks and insurers is facilitated by: the need to accumulate all cash flows in one system, the possibility of significant expansion of the client base, the possibility of providing a full range of services, diversification of capital, increase the rate of profitability of investment resources, the possibility of using the regional network of institutions, increase bank profits in form of commission on the sale of insurance products, etc.

In this context, it became necessary to develop theoretical and methodological approaches to assessing the incomes of different participants in UTC. Based on scientific papers $[1 ; 3 ; 4 ; 5 ; 8 ; 11 ; 13]$, the authors of the study modeled this process as follows. Let the elementary UTC include: enterprise A - producer of main products, enterprise B - consumer of basic products, commercial bank - B, insurance company - SC. Enterprise-manufacturer A has the necessary resources and production capacities and produces products that have a steady demand for a stable market.

Enterprise B is the consumer of products a, which is used either as a semi-finished product for the production on its basis of its own products, which then sells to the market, or simply promotes products purchased from the company A products on the market. Revenue $\mathrm{B}$ depends on the conditions of purchase and the manufacturer, while the company It is advantageous to buy it in A, as it is cheaper. Therefore, it is important that the consumer enterprise B has its customers and the revenue from the sale of a, and as a result of this income the higher, the more favorable for $\mathrm{B}$ are the conditions of purchase of products from producer $\mathrm{A}$.
Commercial Bank B has at its disposal free financial resources $x(t)$, which it manages at its own discretion. At the same time, the bank has different opportunities for capital investment in order to increase its profit: loan to enterprise A under interest $r$ in order to reduce its production costs or purchase an additional share of ownership B, which allows the bank to be entitled to an additional share of profits $\mathrm{B}$, or simply placing funds on capital market.

The insurance company SK also has available free financial resources and has various opportunities for capital investments in order to increase its profit: acquisition of additional share of ownership, granting loans to participants of UTC, placement of funds in the financial market, etc. As a result, the model takes into account that the market value of enterprise B and the free financial resources of the bank and the insurance company are constant at any time $t$. In this context, the revenues of enterprises, the bank, the insurance company were assessed in the course of their joint cooperation in the UTC. For a fixed point $\left.t\left(t \in\left[t_{0}, T\right]\right)\right)$, the possible income of each of the participants in the UTC was determined. At the same time, it has been taken into account that tax deductions for any UTC do not change the results of the study, therefore, tax deductions are not considered for simplification of the conclusions of further research.

Let $y_{0}(t)$ - be the optimal volume of output at time $t$. A part of this product in the volume $y(t)\left(y(t) \leq y_{0}(t)\right)$ company A sells to consumer $\mathrm{B}$, and the rest of products a in volume a $\Delta y(t)=y_{0}(t)-y(t)$. It is necessary to find the relation between the volumes $y(t)$ and $\left.y_{0}(t)\right)$, which at time $t$ is the most advantageous for all participants of the UTC. The income of the manufacturer $\mathrm{A}$ at the moment $t$ from trade with the enterprise B is $D_{1}(t)=c_{1} y(t)$, and the income from trading on the market is $-D_{2}(t)=c_{2} \Delta y(t)$. At the same time, $c_{1}$ - the selling price to the consumer $B$, and $c_{2}$ - the selling price and on the market.

Taking into account the specific costs $w(x(t), y(t))$, the price of ${ }_{c l}$ sales of products to the consumer B will look like this:

$$
c_{i}=w\left(x(t), y_{0}(t)+\zeta_{1}\left\lfloor c_{0} \pm w\left(x(t), H_{0}(e)\right)\right\rfloor\right.
$$

where, $\xi_{2}=$ const, $0 \leq \xi_{2} \leq 1$

Thus, the income of the manufacturer $\mathrm{A}$ at the moment $t$ from trade with enterprise $\mathrm{B}$ is:

$$
D_{1}(t)=c_{1} y(t)=\left[\xi_{1} c_{0}+\left(1-\xi_{1}\right) w\left(x(t), y_{0}(t)\right)\right] y(t)
$$

The price of sales of products in the market in the volume $\Delta y(t)$ will be calculated:

$$
\left.c_{2}=w\left(0, y_{0}(t)\right)+\xi_{2}\left[c_{0}-w(0), y_{0}(t)\right)\right]
$$

Accordingly, the income of the manufacturer A at the moment $t$ from trade in the market in the volume $\Delta y(t)$ will be calculated:

$$
D_{2}(t)=c_{2} \Delta y(t)=\left[\xi_{2} c_{0}+\left(1-\xi_{2}\right) w\left(0, y_{0}(t)\right)\right] \Delta y(t)
$$


Such income $\left(D_{1}(t)+D_{2}(t)\right)$ has enterprise A at the time $t \in\left[t_{0}, T\right]$ from the trade of its products. As a result of the study, the integrated profit of each participant in the united territorial community from the joint participation at time $t \mathrm{\epsilon}$ $\left[t_{0}, T\right]$ was determined. Therefore, the profit of producer A at time $\mathrm{t}$, which will be denoted as $P_{A}(t)$ and takes into account the income of enterprise $\mathrm{A}\left(D_{1}(t)+D_{2}(t)\right)$, the specific costs $\mathrm{w}(x(t), y 0(t))$, the amount bank loan $K B(t)$, bank interest rate $r_{B}$, loan amount of insurer $\operatorname{KCS}(t)$, interest rate on loan of insurer $r_{\mathrm{CK}}$, represented as:

$$
P_{A}(t)=\left(D_{1}(t)+D_{2}(t)\right)-w\left(x(t), y_{0}(t)-\left(1+r_{5}\right) K_{5}(t)-\left(1+r_{C K}\right) K_{C K}(t)\right.
$$

Enterprise profit B at time $t$, which is denoted as PV (t).

At the same time, it is taken into account that from the very beginning of its work in UTC the bank owns a certain share $\alpha 0\left(0<\alpha_{0}<1\right)$ of the property of enterprise B. Then:

$$
P_{B}(t)=\left(1-\alpha_{0}\right)\left[c_{0} y(t)-c_{1} y(t)\right\rfloor
$$

Bank Б profit at time $t$, which is denoted as $\mathrm{P}_{\mathrm{5}}(\mathrm{t})$, takes into account the interest on the $K_{B}(t)$ and the share $\alpha_{0}$ of enterprise B profit:

$$
P_{5}(t)=\alpha_{0}\left\lfloor c_{0} y(t)-c_{1} y(t)\right\rfloor+r K_{5}(t)
$$

Profit of the insurer $\mathrm{CK}$ at time $\mathrm{t}$, which will be denoted as $\mathrm{P}_{\mathrm{CK}}(\mathrm{t})$, takes into account the interest on the loan of $\mathrm{K}_{\mathrm{CK}}(\mathrm{t})$ :

$$
P_{C K}(t)=r K{ }_{C K}^{(t)}
$$

The constructed model will take into account the income of each participant of the united territorial communities in their joint cooperation and optimize the connections.

\section{CONCLUSION}

In the activity of the united territorial communities, a tendency has appeared in the ratio between own and attracted sources of financing of enterprises, which is characterized by a greater dependence of enterprises from financial and credit institutions and the market of loan capital. Hence, changes in the ratio of own and attracted sources of funding for UTC enterprises contribute to the close integration of banking and industrial capital. Capital pooling and concentration of administrative functions in UTC will make it possible to realize significant financial projects more effectively and respond to changes in market conditions. It has been established that participation in UTC $\mathrm{s}$ of banks, insurance, leasing, trust, investment companies, etc., will facilitate financial cooperation within UTC, as financial and lending institutions accumulate the main source of financing of the economy - money capital. It is substantiated that the activity of banks in the UTC is quite promising for the development and ensuring financial stability, since they concentrate cash, deposits, settlements, securities and other assets of the entities of UTC. At the same time, the presence in the UTC of the insurance division will reduce the risk of operating UTC $\mathrm{s}$, in particular, increase the reliability of business operations, support the continuity of production and sales activities of enterprises. The proposed model for estimating the income received by each participant in UTC with their joint cooperation will provide both scientific and practical directions for the implementation of the financial policy of UTC. To solve the problems of financial development of UTC, issues of theoretical and methodical principles for the regulation of financial transformations of UTC , management of financial risks in UTC, diagnostics of possible crisis phenomena in the strategic development of UTCs, their emergence remain relevant.

\section{REFERENCES}

[1] H.Guo, Z. Su, and D. Ahlstrom, "Business model innovation: The effects of exploratory orientation, opportunity recognition, and entrepreneurial bricolage in an emerging economy", Asia $\mathrm{Pa}$. J. Manag., 2016, [Online]. Available: https://doi.org/10.1007/s10490015-9428-x. Accessed on: June 11, 2019.

[2] M. Bondarchuk, M. Bublyk, and O. Vivchar, "Management of sanation innovations as a part of economic security industrial and financial group", in Security of the XXI century: national and geopolitical aspects, Prague: Nemoros S.R.O, Czech Republic, 2019, pp. 325-486.

[3] D. Vasylkivskyi, M. Voinarenko, and V. Nyzhnyk " Cluster policy as a factor of increasing the efficiency of functioning of socio-economic systems ", Bulletin of economic science of Ukraine, pp. 86-95, 2017.

[4] H. Vozniak, Financial potential of the region and problems of its evaluation. [Online]. Available: http://www.rusnauka.com/15_ APSN_2010/Economics/66671.doc.htm. Accessed on: June 15, 2019.

[5] O. I. Gonchar, K. Ya. Melnychuk, and M. V. Gonchar, " Theoretical principles of forming an effective system for managing the economic potential of the enterprise", Herald of Khmelnytskyi National University, Ekonomical sciences, vol. 6(1), pp. 207-209, 2018, [Online]. Available: http://nbuv.gov.ua/UJRN/Vchnu_ekon_2018_ 6(1)_40. Accessed on: June 15, 2019.

[6] O. Demianchuk "Components of the financial potential of the administrative-territorial unit", Scientific Notes of the National University of Ostroh Academy, Economy Series, iss. 25, pp. 95-103, 2014.

[7] Kh.B. Dzhuryk "Foreign experience of financing local selfgovernment", Modern Economics, vol. 12, pp.69-74, 2012. [Online]. Available: https://modecon.mnau.edu.ua. Accessed on: June 15, 2019.

[8] T.F. Kutsenko, and Y. Y. Dudarenko, "United Territorial Communities in Ukraine: A Brief Analytical Review", Economy and the state, vol. 3, pp. 64-70, 2017. [Online]. Available: http://nbuv.gov.ua/UJRN/ecde_2017_3_15. Accessed on: June 15, 2019.

[9] O. Matveeva, "Institutionalization of financial support of local selfgovernment under decentralized management", Governance, vol. 2 (38), pp. 10-16, 2012.

[10] D. C. North, and R. P. Thomas, The Rise of the Western World: A New Economic History, Cambridge, 1973.

[11] V. Palchuk, "Development of economic potential of communities in the framework of decentralization reform", Ukraine: events, facts, comments, vol. 11, pp. 38-50, 2018. [Online]. Available: http://nbuviap.gov.ua/images/ukraine/2018/ukr11.pdf. Accessed on: June 13, 2019

[12] O. Tymoshenko "Financial potential as a basis for socio-economic development of the territorial community", Bulletin of the National Bank of Ukraine's Banking University, vol. 1, pp. 123-126, 2012.

[13] O. Khistieva, "Financial potential of the region: theory and practice". [Online]. Available: http://archive.nbuv.gov.ua/portal/soc gum /Tiru/2012_34/Histeva.pdf. Accessed on: June 18, 2019.

[14] V. Boronos, "Assessment of the role of the financial potential of the region in the study of stability of economic development of the territory", Bulletin of Sumy National Agrarian University, vol. 2, pp. 76-85, 2011. 